\title{
Heterogeneity of GABAergic Cells in Cat Visual Cortex
}

\author{
H. Demeulemeester, ${ }^{1,2}$ F. Vandesande, ${ }^{1}$ G. A. Orban, ${ }^{2}$ C. Brandon, ${ }^{3}$ and J. J. Vanderhaeghen ${ }^{4}$ \\ 'Laboratory of Neuroendocrinology and Immunological Biotechnology, Zoological Institute, 3000 Leuven, Belgium, \\ 'Laboratory of Neuro- and Psychophysiology, Campus Gasthuisberg, 3000 Leuven, Belgium, ${ }^{3}$ Department of Biological \\ Chemistry and Structure, The Chicago Medical School, North Chicago, Illinois 60064, and 4 Laboratory of Neuropathology \\ and Neuropeptide Research, U.L.B. Campus Anderlecht Erasme, 1070 Brussels, Belgium
}

\begin{abstract}
Antibodies against neuropeptides and against a vitamin Ddependent calcium-binding protein (CaBP) label small cells with nonpyramidal-like morphology in the cat visual cortex (areas 17, 18, and 19). Since GABAergic cells are interneurons, a double-staining procedure was used to test for the coexistence of cholecystokinin (CCK), somatostatin (SRIF), neuropeptide $Y$ (NPY), corticotropin-releasing factor (CRF), vasoactive intestinal polypeptide (VIP), and CaBP with glutamic acid decarboxylase (GAD). Our results show that CRF and VIP do not coexist with GAD, while the 3 other peptides and CaBP do. Hence GAD-positive cells can be subdivided into 4 broad groups: (1) cells that are only GAD-positive, (2) cells that are GAD- and CaBP-positive, (3) GAD-positive neurons also containing $C C K$, and (4) GAD-positive cells that also contain SRIF. A small subset of class 2 also contains SRIF and most cells of class 4 also contain NPY. The 4 classes of GAD-positive cells differ in laminar position: class 1 predominates in layers IV and V, classes 2 and 3 in the upper laminae (II and III), and class 4 in the deepest layer (VI).
\end{abstract}

A series of experiments by Sillito and coworkers (Sillito, 1974, 1975a, b; Sillito et al., 1980; Vidyasagar and Heide, 1986) has shown that several functional properties of visual cortical cells depend on GABA-mediated inhibition: iontophoretic application of the GABA antagonist bicuculline abolishes orientation selectivity and direction selectivity, reduces end-stopping, and shifts the ocular dominance from extreme values to those of class 4 in many cortical cells. This multiplicity of physiological effects of GABAergic inhibition is to a certain extent paralleled by a morphological diversity of GABAergic cells. Indeed, most stellate cells, basket cells, and axoaxonic cells or chandelier cells have been shown to contain GABA (Ribak, 1978; Hendrickson et al., 1981; Hendry et al., 1983b; Houser et al., 1983; Somogyi et al., 1983, 1984b, 1985; Somogyi and Hodgson, 1985). It has also been shown that GABAergic terminals can end on different parts of the target cell (Freund et al., 1983; Somogyi et al., 1985) and thereby exert different types of action on such cells. Recent immunocytochemical studies have shown that several peptides coexist with GABA (Hendry et al., 1984b; Schmechel et al., 1984; Somogyi et al., 1984a; Jones and Hendry, 1986; Lin et

Received Apr. 27, 1987; revised Sept. 8, 1987; accepted Sept. 10, 1987.

This work is a result of research sponsored by grants from the Belgian NFWO and the Queen Elisabeth Foundation. H.D. was supported by IWONL.

Correspondence should be addressed to Hilde Demeulemeester, Zoological Institute, Naamsestraat 59, 3000 Leuven, Belgium.

Copyright (C) 1988 Society for Neuroscience $0270-6474 / 88 / 030988-13 \$ 02.00 / 0$ al., 1986). In addition, Somogyi et al. (1984a) suggested that the presence of the peptides cholecystokinin (CCK) and somatostatin (SRIF) subdivides the GABAergic population of visual cortical cells. The present experiments were undertaken to further investigate the biochemical multiplicity of GABAergic cells using immunocytochemical techniques. We have tested the coexistence of GABA not only with the peptides CCK, SRIF, and neuropeptide Y (NPY), but also with corticotropin-releasing factor (CRF), vasoactive intestinal peptide (VIP), and a vitamin D-dependent calcium-binding protein $(\mathrm{CaBP})$, using a doubleimmunocytochemical procedure.

Little information is available about the regional distribution of GABAergic and peptidergic cells in the visual cortex. Therefore, our second aim was to compare the distributions of GABApositive, $\mathrm{CaBP}$-positive, and neuropeptide-positive neurons between different visual areas and different layers of the visual cortex. Differences in these distributions could yield a clue as to how the varying physiological effects of $G A B A$ are related to the biochemical subtypes of GABAergic neurons.

\section{Materials and Methods}

Animals and tissue preparation. Animals were deeply anesthetized with a large dose of pentothal $(60 \mathrm{mg} / \mathrm{kg}$, i.v.). The brains were fixed by cardiac perfusion followed by postfixation. Different fixation methods were used in different animals as follows: (1) $0.2 \%$ paraformaldehyde and $0.03 \%$ glutaraldehyde in $0.1 \mathrm{~m}$ phosphate buffer, $\mathrm{pH} 7.4$, followed by a $2 \mathrm{hr}$ postfixation in the same solution at $4^{\circ} \mathrm{C}$; (2) $4 \%$ paraformaldehyde in $0.1 \mathrm{~m}$ phosphate buffer, $\mathrm{pH} 7.4$, and a $24 \mathrm{hr}$ postfixation performed at room temperature; (3) Bouin Hollande fluid containing $10 \%$ of a saturated $\mathrm{HgCl}_{2}$ solution, followed by postfixation for $48 \mathrm{hr}$ at room temperature; and (4) $2 \%$ paraformaldehyde in $0.15 \mathrm{M}$ sodium phosphate buffer, $\mathrm{pH} 7.4$, conlaining $0.002 \% \mathrm{CaCl}_{2}$, with $1 \mathrm{hr}$ of postfixation in the same fixative; the $\mathrm{pH}$ was then raised to 10 by the addition of $\mathrm{NaOH}$. The brain was further postfixed overnight in this solution at

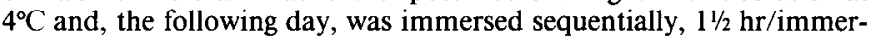
sion, in PBS solutions containing, respectively, 5, 10, and 20\% dimethyl sulfoxide (DMSO). Then the tissue, still immersed in 20\% DMSO, was frozen in liquid nitrogen. Tissue frozen in this manner can be stored in the freezer over a long period.

The 9 animals used in this study were part of another, unrelated physiological study. Only the hemispheres contralateral to the sites of single-cell microelectrode registration were used. Seven cats were used exclusively for the present experiments, and both hemispheres of these animals could be used. Quantitative measurements (proportions of cells) were only performed on hemispheres of cats not used in physiological experiments. Three of the latter cats were intracortically injected with colchicine ( $1 \mu \mathrm{l}$ containing $6 \mu \mathrm{g}$ ) according to the procedure of Somogyi et al. (1983). Intraventricular injections of colchicine $(50 \mu \mathrm{l}$, containing $750-1000 \mu \mathrm{g}$ ) were performed on 2 cats anesthetized with alfatesine $(0.3 \mathrm{ml} / \mathrm{kg})$. Forty-eight hours after the colchicine injection, the animals were deeply anesthetized with a large dose of pentothal and fixed by cardiac perfusion as described above. Using a Vibratome (Oxford Instruments), 30-50 $\mu \mathrm{m}$ frontal sections were cut throughout the fron- 
tocaudal extent of the lateral, posterolateral, and suprasylvian gyri of the brains fixed according to methods (1), (2), and (4). These sections were collected in $0.01 \mathrm{M}$ Tris-saline buffer and processed for immunocytochemistry. The brains of the animals perfused with fixative (3) were embedded in paraplast after dehydration in ethanol and clearing in xylene. Five micrometer sections were made with a Historange microtome (LKB)

Antisera. All antisera used in the present study were raised in rabbits. Antiserum against CCK has been characterized and described by Lotstra and Vanderhaeghen (1984) and was used at a dilution of 1/8000 in the present study. Antiserum to SRIF has been characterized and described by Dierickx and Vandesande (1979) and was used at a dilution of 1/2000. Antiserum to rabbit brain glutamic acid decarboxylase (GAD) has been prepared and characterized by Brandon (1986) and was used at a dilution of $1 / 1500$. Antiserum to CaBP was the gift of Dr. Pochet and was used at a dilution of 1/10,000. Antiserum to NPY was purchased from Amersham and used at a dilution of 1/4000. Antisera to CRF and VIP were produced using a conjugate of the synthetic peptides to thyroglobulin (Skowsky and Fisher, 1972).

Immunohistochemical procedure. (1) Single-staining: The unlabeled antibody enzyme procedure was used according to Sternberger et al. (1970). The Vibratome sections, free-floating in a 24 -well plate, were incubated in the following solutions: (a) preimmune goat serum diluted $1 / 5$; (b) primary antiserum, overnight, at the optimal dilution; (c) TBS (Tris-buffered saline containing $0.01 \mathrm{M}$ Tris, $0.9 \% \mathrm{NaCl}, 0.1 \%$ Triton $\mathrm{X}-100, \mathrm{pH}$ 7.6), 3 washes; (d) goat anti-rabbit (GAR) diluted 1/20, for $30 \mathrm{~min}$; (e) TBS, 3 washes; (f) peroxidase-antiperoxidase (PAP) diluted $1 / 300$, for $30 \mathrm{~min}$; $(\mathrm{g}) \mathrm{TBS}, 3$ washes; and $(\mathrm{h})$ diaminobenzidine (DAB) solution containing $25 \mathrm{mg}$ DAB (Sigma) and $200 \mu 10.03 \% \mathrm{H}_{2} \mathrm{O}_{2}$ in 200 $\mathrm{ml} 0.05 \mathrm{M}$ Tris solution, $\mathrm{pH}$ 7.6. All antisera were diluted in TBS, except the GAD antiserum, which had to be diluted in KPBS $(0.25 \mathrm{M} \mathrm{KCl}$ and $0.25 \mathrm{M} \mathrm{NaCl}$ in $0.1 \mathrm{~m}$ phosphate buffer, $\mathrm{pH} 7.6$ ) in order to yield positive cell body staining.

(2) Double-staining: For the detection of coexistences, we used the double-immunocytochemical procedure, with electrophoretic elution of the first-stage antibodies (Vandesande, 1983). With this technique, the first antigen is localized by a normal PAP procedure. After localization of the first antigen, the antibodies and peroxidase are selectively eluted from the tissue section without removing the colored reaction product identifying the antigenic sites. If the antigen to be localized is not subsequently eluted or denatured by the elution process, the second antigen can be localized by a similar method as was used for the first antigen, employing a substrate that develops a different color. For brown reaction products, 3,3'-diaminobenzidine, and for grayish-blue reaction products, 4-Cl-naphthol, are used. The elution process is the most critical step of the staining procedure. This elution has to be complete, selective, and may not elute or denature the antigen to be localized in the subsequent staining sequence. Completeness of the elution can be checked by performing the first staining sequence, omitting the $\mathrm{DAB}$ reaction, following this by the electrophoresis step and a second application of the first staining sequence, but now omitting the primary antiserum. If this results in negative staining, one can be sure that the elution is complete. The influence of the electrophoretic elution on the concentration and antigenicity of the second antigen can be controlled by comparing 2 adjacent sections, the first stained using the normal PAP method and the second by the same method after electrophoretic elution. No difference between the 2 selections must be observed. In the present experiments all these controls were negative. To perform the electrophoretic elution, the electrophoresis was done in an appropriate mixture of $25 \mathrm{ml} 0.2 \mathrm{M}$ glycine-HCl buffer, $\mathrm{pH} 2.2$, plus $50 \mathrm{ml} \mathrm{di}-$ methylformamide plus $100 \mathrm{ml}$ distilled water. A voltage of $20 \mathrm{~V} / \mathrm{cm}$ (measured over the tissue section) was applied for $2 \mathrm{hr}$.

Specificity tests. For all antisera used in the present study, method specificity was checked on sections adjacent to those that were positively stained. The following tests were performed: (1) substitution of the primary antiserum by normal rabbit serum; (2) sequential omission of various steps in the staining procedure; (3) solid-phase absorption of the primary antiserum on the synthetic antigen coupled to Sepharose 4B (Vandesande et al., 1977).

Serum specificity of the different primary antisera was tested by spotting the different neuropeptides on nitrocellulose sheets, followed by an immunochemical detection of possible cross-reactions using the PAP technique.

Quantitative analysis. Three nontreated cats were used for measuring the laminar distribution of positive neurons in areas 17,18 , and 19 . In all 3 areas, parts of the cortex subserving peripheral vision, as well as parts subserving central vision, were sampled.

In each of the 3 cats, frontal sections were made at 3 different anteroposterior levels (Horsley-Clark coordinates): A12.6-A7.0; A1.0-P2.5; P7.8-P10.2. At each level, sections were stained either immunocytochemically or with cresyl violet. On these sections, 4 sampling strips of $190 \mu \mathrm{m}$ width and extending from the pial surface to the white matter were positioned randomly over the 3 visual areas $(17,18$, and 19). These strips were positioned at least $500 \mu \mathrm{m}$ from the areas $17-18$ and 18-19 borders, and sampled only the parts of area 17 devoted to binocular vision. Each of these strips was subdivided into 6 equal-sized test areas (50 $\mu \mathrm{m}$ high, $190 \mu \mathrm{m}$ wide), randomly positioned in depth over each lamina. Since the height of the test areas is clearly smaller than the thickness of the layers of any cortical layer, thin and thick layers were equally sampled. In each test area, the number of immunoreactive somata or cresyl violet-stained cell bodies was counted.

\section{Results}

\section{Comparison of fixation methods}

Fixation method 4 was finally chosen as the standard method since it overcame all of the problems facing the other fixation procedures. Fixation method 1 (formaldehyde and glutaraldehyde) gave strong background staining. Elution of the antibodies by electrophoresis was difficult in tissue sections fixed with fixatives 1,2 , or 3 , which also yielded inconsistent immunocytochemical reactions for some antisera, most notably those against GAD and VIP.

\section{Effect of colchicine}

Intracortical injections of colchicine had 2 dramatic effects on GAD immunoreactivity in the visual cortex (Fig. 1). The density of GAD-immunoreactive terminal boutons decreased considerably after colchicine injections, and the labeling of the cell bodies was increased, revealing the dendritic morphology (Fig. 2C). These changes appeared up to $2 \mathrm{~mm}$ from the injection site. The intraventricular injections of a large dose of colchicine (50 $\mu$ l, containing 750-1000 $\mu \mathrm{g}$ ) produced similar changes over the whole cortex. Intracortical injections of colchicine had almost no effect on peptidergic immunoreactivity. However, intraventricular injection of a large dose of colchicine produced changes in peptide-positive neurons, which were similar to the changes found in GAD-positive neurons after intracortical injection. The number of immunoreactive terminal boutons decreased, while the dendritic morphology became more clearly visible.

\section{Laminar distribution and morphology of GAD-positive neurons}

Neurons positive for the GAD antiserum were found in all layers of areas 17, 18, and 19 (Fig. 3B). Approximately two-thirds of the cells in layer I were GAD-immunoreactive. In the remaining layers, $15-20 \%$ of the cells were GAD-positive. GAD-positive neurons comprise a heterogenous population of multipolar, round or fusiform-shaped cells. The diameter of the perikarya ranged from 10 to $30 \mu \mathrm{m}$. GAD-positive terminal boutons were found on GAD-positive, as well as on GAD-negative, neurons. The latter group comprised both pyramidal and nonpyramidal cells (Fig. 2, $A, B$ ).

\section{Laminar distribution and morphology of peptidergic neurons}

Only a small percentage of the total neuronal population in the cat primary visual cortex was immunoreactive for any of the neuropeptides. As shown in Figure 4, the peptidergic neurons have a specific laminar distribution. Neurons containing CCK, 

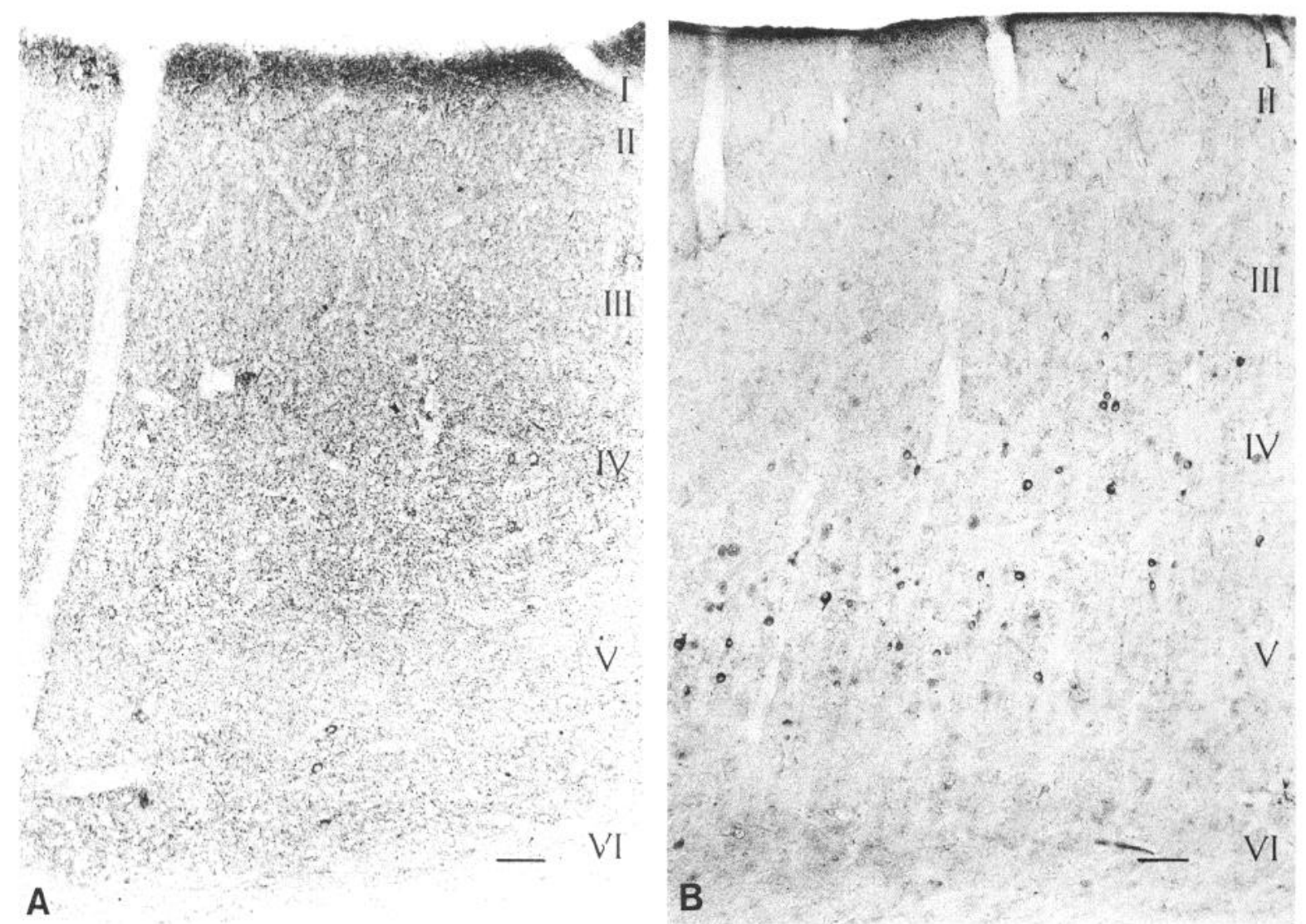

Figure 1. Comparison of GAD immunoreactivity in $(A)$ normal and $(B)$ colchicine-treated cat. The uneven distribution of the immunoreactivity in $(B)$ is due to the intracortical colchicine injection. The photographs clearly show that in the colchicine-treated cat the GAD-positive neurons are more clearly stained, while GAD immunoreactivity in the neuropil is decreased. Calibration bar, $100 \mu \mathrm{m}$.

CRF, and VIP were concentrated in the supragranular layers. Their proportion dropped steadily from lamina I to lamina VI (Fig. 4, $A-C$ ). Neurons containing SRIF or NPY appeared mainly in the infragranular layers (Fig. $4, D, E$ ). The granular layer was almost completely devoid of peptidergic immunoreactivity. All peptidergic neurons were cells with nonpyramidal-like morphology and were of the bipolar, bitufted, or multipolar variety.

CCK-immunoreactive neurons and fibers. Approximately $1-$ $2 \%$ of the total neuronal population in areas 17,18 , and 19 were CCK-immunoreactive. The highest density was found at the layer I/II border, and these neurons were mainly vertically oriented bitufted (width, $\pm 13 \mu \mathrm{m}$; length, $\pm 20-30 \mu \mathrm{m}$ ) or multipolar $( \pm 20 \mu \mathrm{m})$ cells. However, in layer I most CCK cells were horizontally oriented neurons. While the supra- and infragranular layers contained a dense meshwork of CCK-immunoreactive fibers, layer IV was almost devoid of any positive fibers. CCK-positive fibers in layer I had an essentially tangential course. All layers, except layer IV, contained CCK-positive terminal boutons contacting immunonegative cells.

VIP-immunoreactive neurons and fibers. In the 3 areas that were also VIP-immunoreactive, neurons represented approximately $1-2 \%$ of the total neuronal population. The highest density was found at the layer I/II border. These neurons were mainly vertically oriented bipolar or bitufted (width, $\pm 10 \mu \mathrm{m}$; length, $\pm 20 \mu \mathrm{m}$ ) (Fig. $2 F$ ). Only a few VIP-positive fibers were observed. In layers II and III they ran perpendicular to the cortical surface without any considerable arborization.

$C R F$-immunoreactive neurons and fibers. Only $0.2-0.3 \%$ of the total neuronal population was immunoreactive for CRF and these were chiefly bipolar cells (width, $\pm 10 \mu \mathrm{m}$; length, \pm 20 $\mu \mathrm{m})$. Because of their strong immunoreactivity, the morphology of the CRF-positive cells was very clear. These positive cells were mainly horizontally oriented in layer I (Fig. 2D) and vertically oriented in layer II (Fig. $2 G$ ). Some of the latter were bitufted. CRF-immunoreactive cells were absent in the granular and infragranular layers. Almost no CRF-immunoreactive fibers were observed.

SRIF- and NPY-immunoreactive neurons and fibers. SRIFand NPY-immunoreactive cells had similar morphological characteristics and laminar distributions and will be described together. Most of the peptidergic cells of the infragranular layers contained SRIF or NPY. SRIF immunoreactivity was found in $0.1-0.5 \%$ of the neurons. NPY immunoreactivity was found in $0.1-0.2 \%$ of the neurons. In layer I, the SRIF- and NPY-positive cells were horizontally bitufted or bipolar, while neurons in layers II-IV were almost always multipolar. Most positive cells in layers $\mathrm{V}$ and VI were horizontally oriented multipolar or bipolar cells (width, $\pm 20 \mu \mathrm{m}$; length, $\pm 20-30 \mu \mathrm{m}$ ), with dendritic branches running parallel to the subcortical white matter (Fig. 2E).

In contrast to the similarity in distribution and morphology of SRIF- and NPY-immunoreactive neurons, the branching patterns of the fibers were very distinct. SRIF-positive fibers were small in diameter and nonpreferentially oriented in the supraand infragranular layers. NPY-positive fibers, some seemingly originating in the white matter, were very thick and formed a 

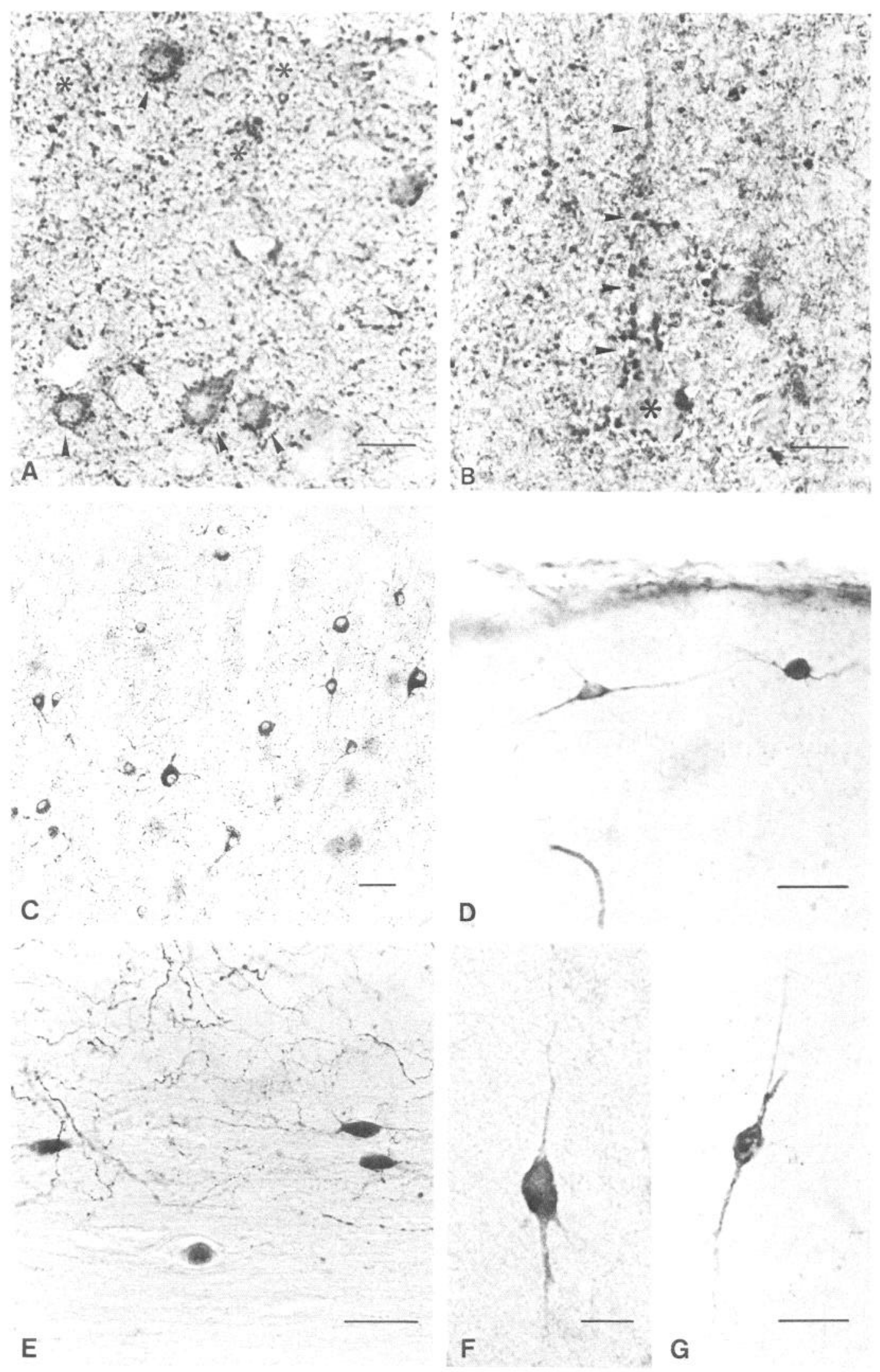

Figure 2. A, GAD-positive neurons in a non-colchicine-treated cat. Cell bodies are faintly stained (arrowheads) and neuronal processes are unclear. GAD-positive boutons are observed surrounding both immunoreactive and nonimmunoreactive (asterisk) neurons. Calibration bar, $25 \mu \mathrm{m}$. $B$, Nonimmunoreactive layer III pyramidal cell (asterisk) surrounded by GAD-positive boutons in a non-colchicine-treated cat. Arrowheads, GADpositive boutons contacting the soma and apical dendrite. Calibration bar, $25 \mu \mathrm{m}$. $C$, GAD-immunoreactive neurons in a colchicine-treated animal. Notice the dense labeling of the neurons and the clear morphology of the cells. GAD-immunoreactive boutons are less frequently observed than in normal cats. Calibration bar, $25 \mu \mathrm{m}$. D, CRF-positive horizontal-oriented neurons in layer I of area 19. Calibration bar, $50 \mu \mathrm{m}$. E, Three NPYpositive neurons in layer VI of area 17 embedded in a NPY-positive fiber plexus. Cells are horizontally oriented with their dendritic branches running parallel to the subcortical white matter. Calibration bar, $50 \mu \mathrm{m}$. F, VIP-positive bipolar neuron in layer II of area 17 . Calibration bar, 25 $\mu \mathrm{m}$. $G$, CRF-positive bipolar neuron in layer II of area 17. Calibration bar, $50 \mu \mathrm{m}$. 

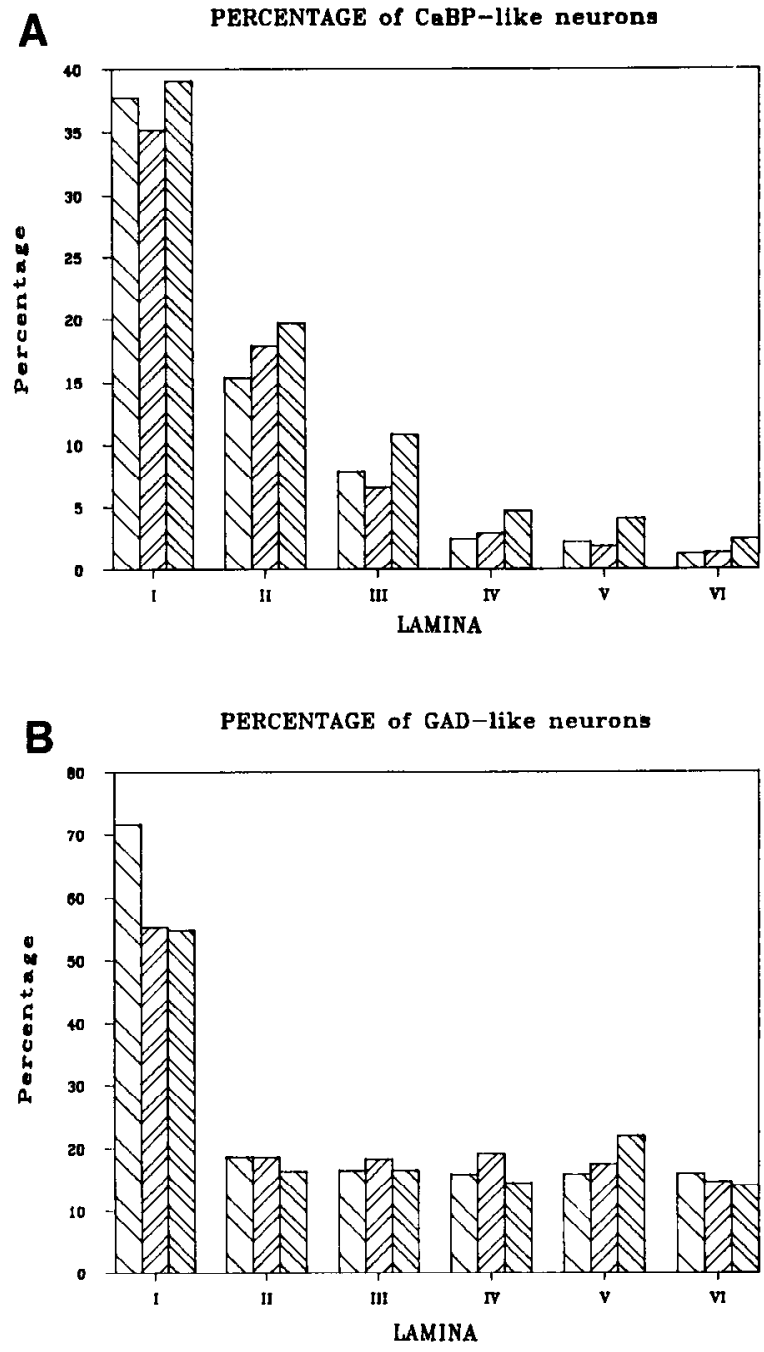

Figure 3. Laminar distribution of immunoreactive neurons expressed as a percentage of the total neuronal population in areas 17,18 , and 19. $A$, CaBP-positive neurons. $B, \mathrm{GAD}$-positive neurons. The average laminar proportions were calculated sampling the following numbers of test areas: $n=102, n=92, n=46$ for CaBP-positive cells in areas 17,18 , and 19 , respectively; $n-100, n=74, n=58$ for GAD-positive cells in areas 17,18 , and 19 , respectively. For laminae II-VI, each test area contained, on average, 30-50 neurons counted on adjacent cresyl violet-stained sections. For lamina I each test area contained only 7-8 neurons. Thus, for example, for area 17 the proportion of CaBP-positive cells was calculated on 3060-5100 neurons for laminae II-VI and on 740 neurons for lamina I.

dense meshwork, sparing layer IV, through which they ran perpendicular without any arborization (Fig. $5 A$ ). SRIF-containing boutons were larger, more numerous, and more clearly surrounded the cell bodies than those containing NPY. These SRIFimmunoreactive pericellular networks, which could represent nerve terminals, occurred on nonimmunoreactive short-axon cells in all layers except layer IV, and occasionally also on pyramidal cells of layer II (Fig. $5 B$ ). After intraventricular colchicine injection, almost all of these boutons disappeared, while the SRIF-positive fibers became more visible.

Laminar distribution and morphology of a vitamin $D$-dependent calcium-binding protein ( $\mathrm{CaBP})$-positive neurons

The number of CaBP-immunoreactive cells comprised approximately $6 \%$ of neurons in area $17,5 \%$ in area 18 , and $7 \%$ in area 19. Intraventricular injection of colchicine had hardly no effect on these immunoreactive neurons. They were found in all layers of the cat primary visual cortex, although they were more frequent in the supragranular layers. (Fig. 3A) They belonged to all varieties of interneurons (Fig. $6 \mathrm{~A}$ ), but a few positive small, pyramidal-like cells were observed in layer II (Fig. $6 \mathrm{~B}, \mathrm{C}$ ). In layer I, most CaBP-positive neurons were small and multipolar, while in layers II and III they were large multipolar, bipolar, or bitufted. In the infragranular layers, they were horizontally oriented multipolar or bipolar cells. Many cells in the subcortical white matter were also CaBP-positive. A plexus of CaBP-positive fibers was found in the upper layers (Fig. 5C). In addition, a number of fibers originating from bipolar or bitufted cells in the superficial layers ran perpendicularly through laycr IV.

\section{Double-stained neurons}

Double-immunocytochemical procedures were performed for all possible combinations of peptides, for each peptide and GAD or $\mathrm{CaBP}$, and for CaBP and GAD. As the immunoreactivity of GAD seemed to be destroyed by electrophoresis, the antiserum against GAD always had to be used in the first staining sequence. For the remaining combinations, those antisera that gave the lowest background staining and that could be totally eluted from the tissue section were used during the first staining sequence. Because anti-CaBP and anti-NPY antisera had a very strong affinity for their antigens, they could not be completely eluted from the tissue section by electrophoresis. These 2 antisera were therefore always used during the second staining sequence. Since electrophoresis may partially elute the antigens from the tissue section, the second staining sequence might be expected to reveal fewer positive cells. As a consequence, the number of double-labeled cells expressed as a proportion of cells labeled with the first antibodies might have been underestimated. Control experiments, in which double-staining in both directions has been performed, showed that this underestimation was practically negligible.

The main objective of the present study was to determine which antigens coexisted with one another. Our results show that (1) GAD can coexist with CaBP, CCK, SRIF, and NPY, but not with CRF and VIP, and (2) CRF and VIP coexist. The GABAergic population in the cat visual cortex can therefore be subdivided according to these coexistences. In the supragranular layers a number of GAD-immunoreactive cells were also labeled by antisera against $\mathrm{CCK}$ and $\mathrm{CaBP}$ (Fig. $7 A$ ), but not by those against VIP and CRF. In the infragranular layers, a number of GAD-positive neurons were also labeled for SRIF and NPY. These results are illustrated in Figure 7 and summarized in Table 1.

It is worth pointing out that most, if not all, CCK-, SRIF-, and NPY-positive neurons are also GAD-positive, though only a minority of GAD-positive cells contains these peptides. As summarized in Figure 8 and illustrated in Figure 7, there was little coexistence between CaBP and these peptides. Only $7 \%$ of the CaBP-positive cells were peptidergic, the most frequent combination being $\mathrm{CaBP}$ and SRIF. Of the many possible combinations of the peptides tested, only 2 were actually observed: SRIF coexisted with NPY, and VIP with CRF. Our results suggest that the NPY-positive population is a subpopulation of the SRIF-positive cells, and that the CRF-positive population is a subpopulation of the VIP-positive neurons. As shown in Figure 8 , GABAergic cells can be subdivided into 4 classes with dif- 

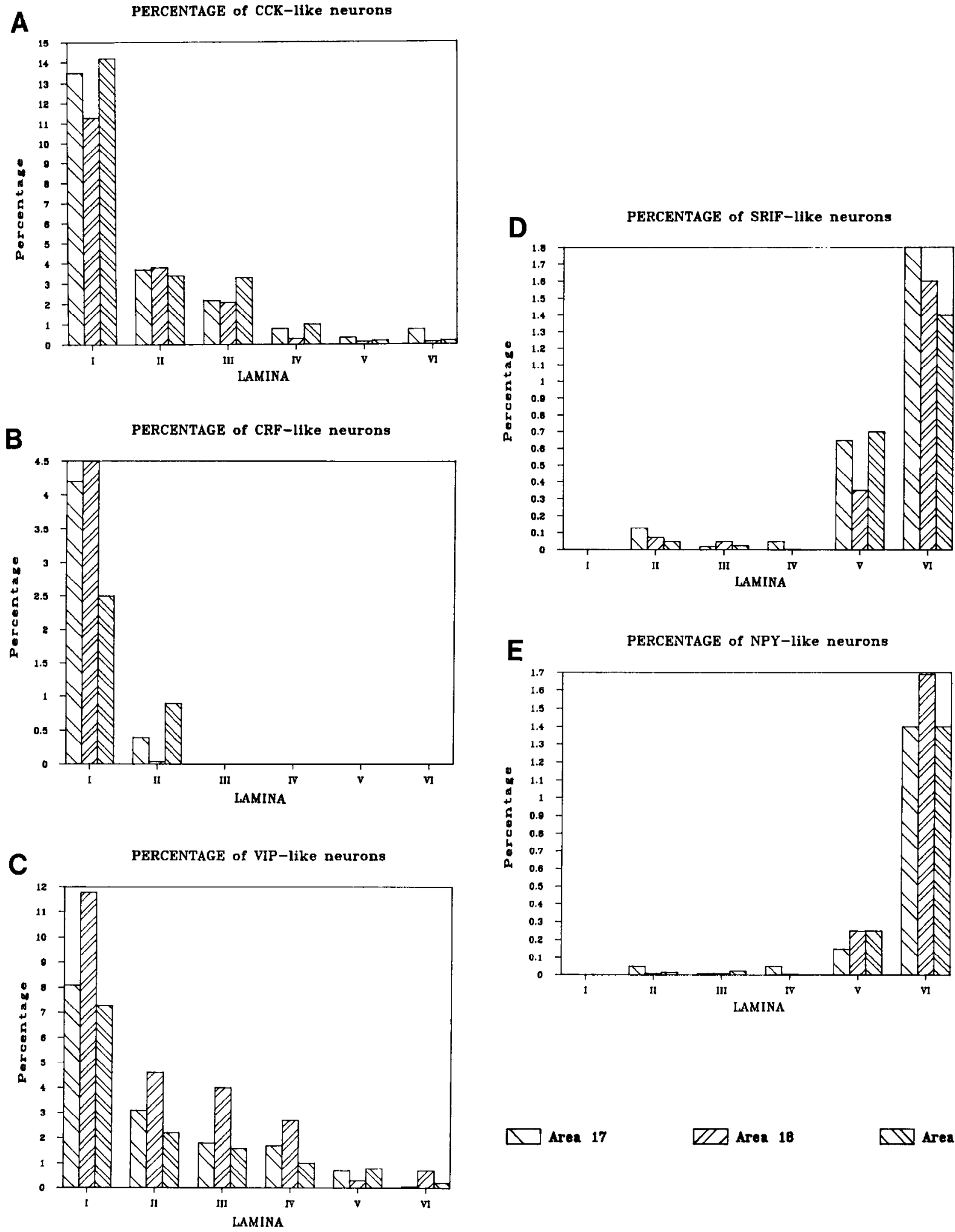

Figure 4. Laminar distribution of immunoreactive neurons expressed as a percentage of the total neuronal population in areas 17,18 , and 19 . $A$, CCK-positive neurons. $B$, CRF-positive neurons. $C$, VIP-positive neurons. $D$, SRIF-positive neurons. $E$, NPY-positive neurons. The average laminar proportions were calculated for the following number of samples: $n=114, n=72, n=50$ for CCK-positive cells in areas 17, 18, and 19, respectively; $n=30, n=23, n=8$ for CRF-positive cells in areas 17, 18, and 19, respectively; $n=36, n=18, n=10$ for VIP-positive cells in areas 17,18 , and 19, respectively; $n=80, n=60, n=50$ for SRIF-positive cells in areas 17, 18, and 19, respectively; and $n=80, n=50, n=$ 45 for NPY-positive cells in areas 17, 18, and 19, respectively. For laminae II-VI, each test area contained, on average, 30-50 neurons counted on adjacent cresyl violet-stained sections. For lamina I, each test area contained on average only 7-8 cells. Thus, for example, for area 17 the proportion of CCK-positive cells was calculated on 3420-5700 neurons for laminae II-VI and on 800 neurons for lamina I. 


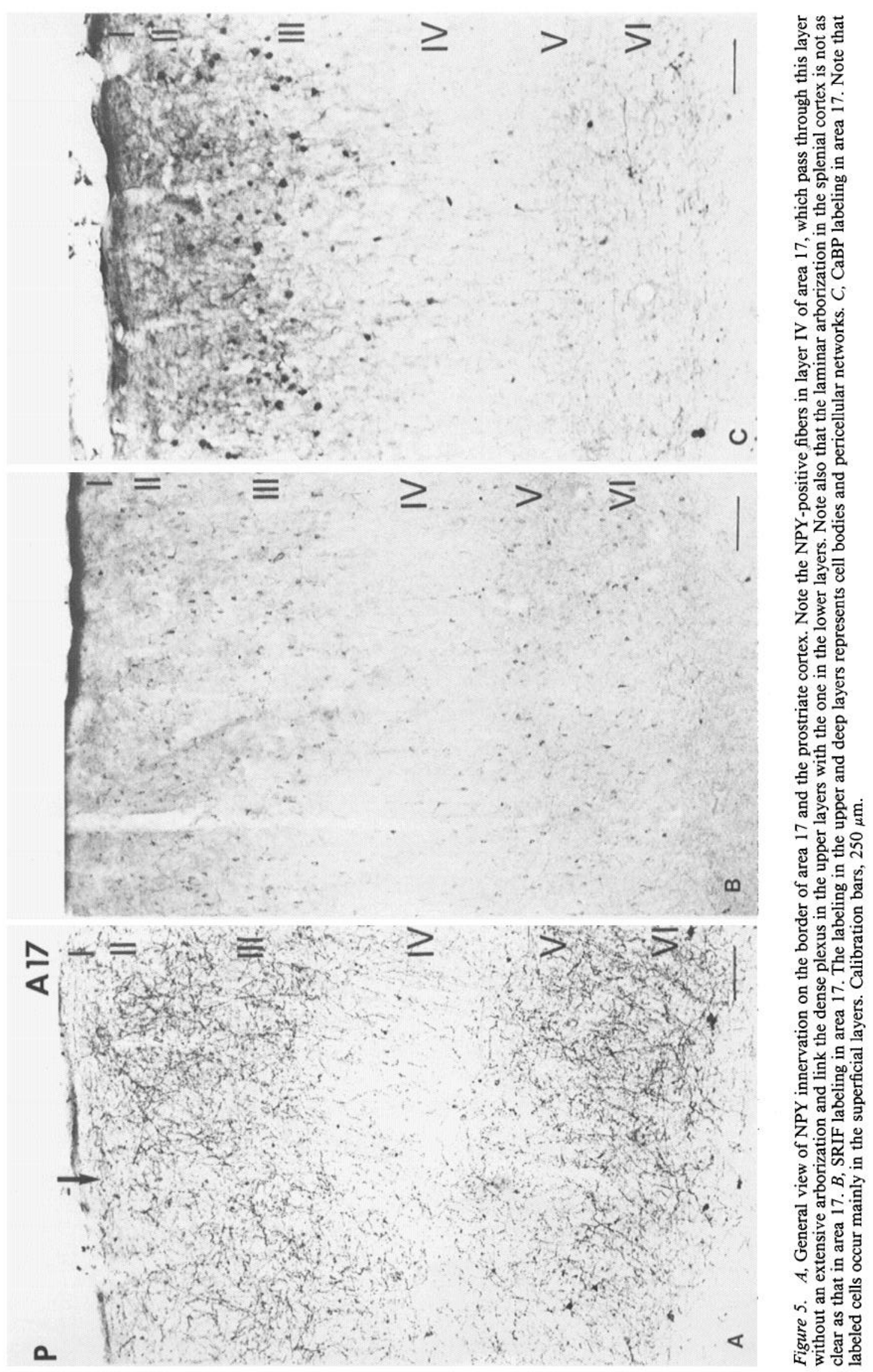



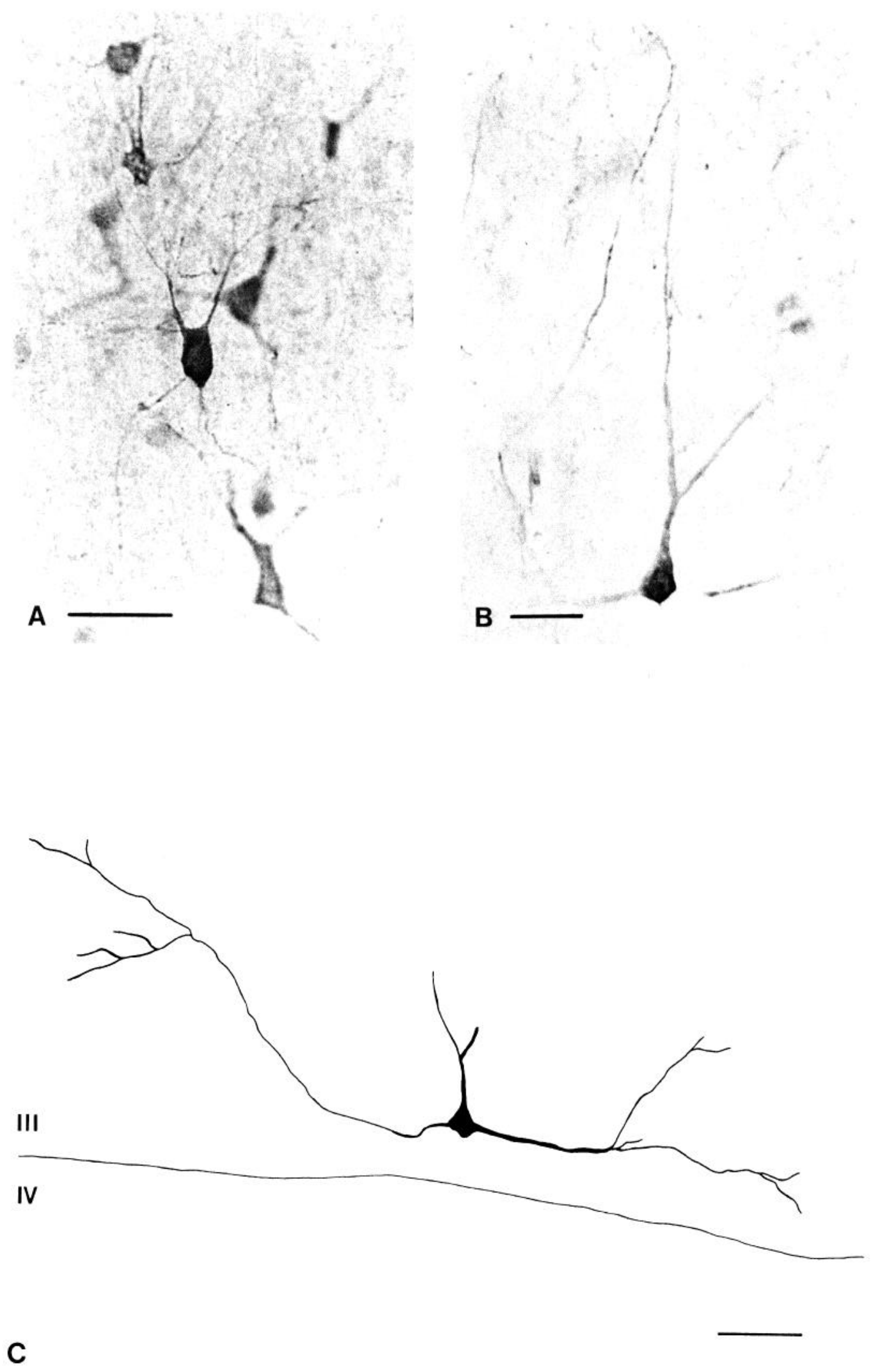

Figure 6. A, CaBP-positive neurons in layer II of area 18. Various types of interneurons are CaBP-positive. B, Small pyramidal-like neuron in layer II of area 19 immunoreactive for CaBS. $C$, Drawing of a small pyramidal-like cell of area 17. Calibration bars, $50 \mu \mathrm{m}$. 

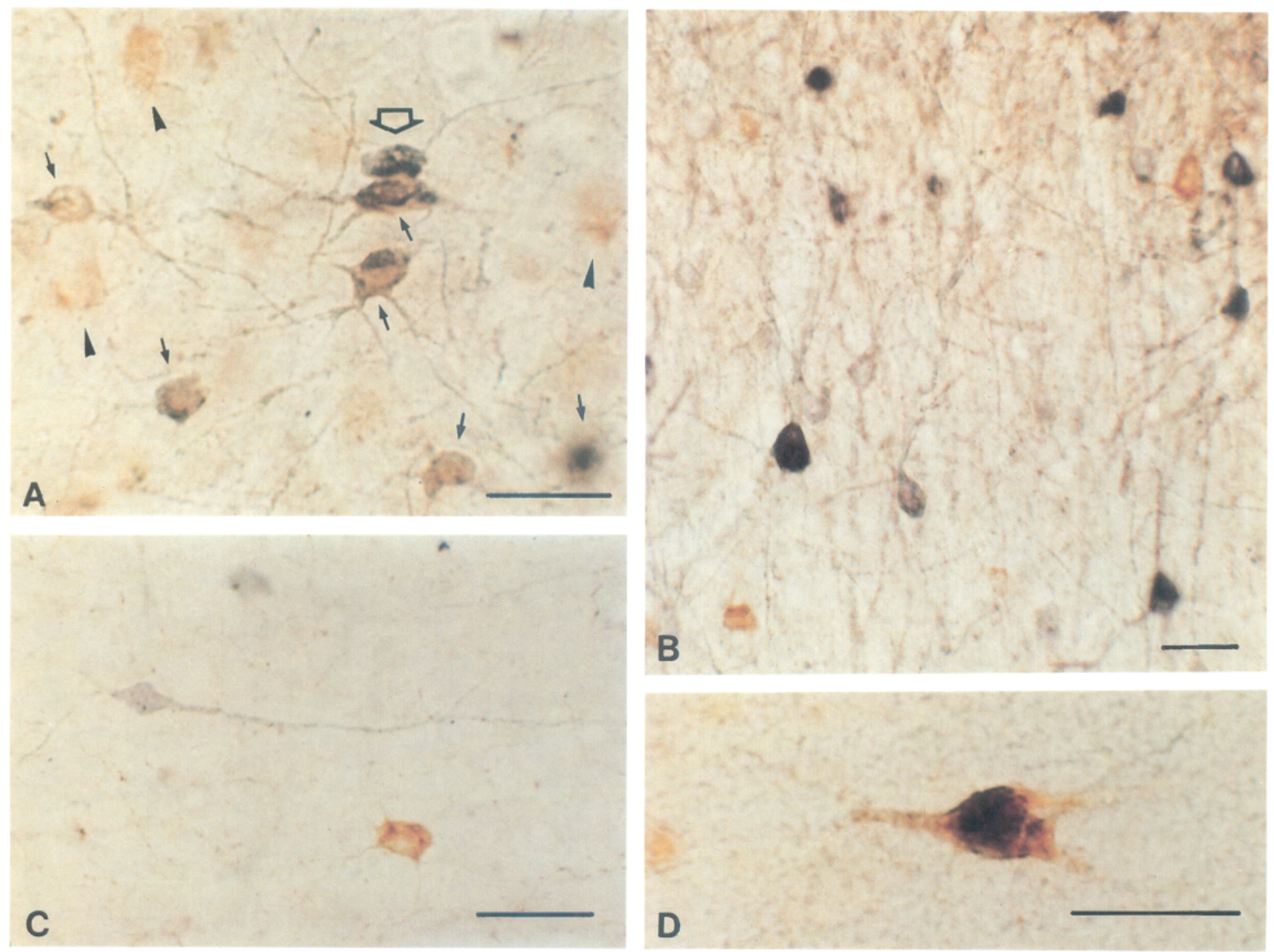

Figure 7. Double-immunocytochemical labeling on single sections. $A$, Doublc-labcling with the anti-GAD serum, resulting in a brown color (arrowheads) and the anti-CaBP serum, resulting in a blue color (open arrow). Many neurons are double-labeled (arrows). Because of the thickness of the section, a number of immunoreactive cells are out of focus, for the same reason that the nucleus of some cells can be cut, but most nuclei will be intact. Since this photograph was focused on a plane close to the section surface, nuclei are only apparent in cells in sharp focus (the doublelabeled cells). $B$, Double-staining with the anti-CRF serum (brown) and the anti-CaBP serum (blue). No double-labeled neurons are present. $C$, Double-staining with the anti-NPY serum (brown) and the anti-CaBP serum (blue). No double-labeled neurons are present. $D$, Double-labeled neuron after double-staining with the anti-SRIF serum and the anti-NPY serum. The result is a mixed color. Calibration bars, $50 \mu \mathrm{m}$.

ferent laminar distributions. The majority of GABAergic cells (two-thirds) does not contain detectable amounts of the antigens investigated in this study. Virtually all layer IV cells and many cells of the other layers belong to this category. The second class of GABAergic cells (about one-fifth) contains $\mathrm{CaBP}$; this group occurs mainly in the supragranular layers. The third category of GABAergic cells (one-tenth) contains CCK; this class also occurs in the supragranular layers. A small fraction of GABAergic cells contains SRIF; these last cells occur in the infragranular layers, and most of them also contain NPY.

\section{Discussion}

The results of the present study confirm previous reports on the distribution of GAD-immunoreactive neurons in the cat visual cortex (Somogyi et al., 1983) and on the coexistence of this enzyme with the neuropeptides SRIF, NPY, and CCK in the rat, cat, and monkey visual cortex (Hendry et al., 1984b; Schmechel et al., 1984; Somogyi et al., 1984a; Jones and Hendry, 1986; Lin et al., 1986). In addition, we report here new evidence for the coexistence of a vitamin D-dependent calcium-binding protein with GAD, and for the existence of a group of neurons positive both for VIP and CRF but not for GAD. Finally, our results show that GABAergic, peptidergic, and CaBP-positive innervation is very similar in the 3 cortical areas, 17,18 , and 19.

\section{Distribution of GAD-positive neurons}

GAD-immunoreactive neurons represent $8-15 \%$ of the total neuronal population in the cat visual cortex, a figure close to that reported by Fitzpatrick et al. (1983) and Gabbott and Somogyi (1986). In all 3 areas of the visual cortex examined in the present study, the proportion of GAD-positive cells is much larger in lamina I than in the remaining laminae. Similar laminar percentages have been reported for GAD-positive cells in the rat visual cortex (Lin et al., 1986).

\section{Distribution of peptide-containing neurons}

Although no other studies have been devoted to the laminar distribution of peptidergic cells in the cat visual cortex, our 
Table 1. Colocalization of GAD with other antigens

Proportion of $\mathrm{CaBP}$ - and peptidergic-immunoreactive neurons also positive for GAD (\%)

\begin{tabular}{lrlr}
\hline $\mathrm{CaBP}(+):$ & 63 & $\mathrm{CaBP}(+):$ & 20 \\
$\mathrm{SRIF}(+):$ & 89 & $\mathrm{SRIF}(+):$ & 2 \\
$\mathrm{NPY}(+):$ & 100 & $\mathrm{NPY}(+):$ & 1 \\
$\mathrm{CCK}(+):$ & 89 & $\mathrm{CCK}(+):$ & 11 \\
$\mathrm{CRF}(+):$ & 0 & $\mathrm{CRF}(+):$ & 0 \\
$\operatorname{VIP}(+):$ & 0 & $\operatorname{VIP}(+):$ & 0
\end{tabular}

results are in good agreement with the findings of Wahle et al. (1986) on NPY innervation and with Somogyi et al. (1984a) on CCK innervation.

Several studies have examined the peptidergic innervation of mammalian cortices, in particular of the rat visual cortex. Peptidergic cells in the rat and cat visual cortex can therefore be compared with respect to overall density, laminar distribution, and morphology. It is difficult to compare the overall proportions in peptide-positive cells reported in studies of different laboratories, since these proportions necessarily depend on the sensitivity of the method used. The comparison of our results on VIP and CRF innervation with those obtained in the rat (McDonald et al., 1982b; Merchenthaler et al., 1982; Connor and Peters, 1984; Merchenthaler, 1984) suggest that the proportion of VIP-positive cells is somewhat larger in the rat cortex than in the cat cortex, while the reverse is true for CRF. Our own unpublished observations on the rat visual cortex support this view. Hendry et al. (1984a) compared the number of SRIFand NPY-positive cells between different species and concluded that the number of positive cells was higher in the rat cortex than in the monkey cortex. Our experiments do suggest that the proportions of SRIF, CCK, and NPY are also higher in the rat than in the cat visual cortex $(H$. Demeulemeester, F. Vandesande, and G. A. Orban, unpublished observations).

Despite this difference in overall staining, the laminar distribution of peptidergic cells seems to be relatively similar in different species. There seems to be general agreement that the CCK-, CRF-, and VIP-positive cells occur mainly in the supragranular layers in the rat and cat visual cortex (McDonald et al., 1982b, c; Merchenthaler et al., 1982; Hendry et al., 1983a; Peters et al., 1983; Swanson et al., 1983; Connor and Peters, 1984; Magistretti et al., 1984; Merchenthaler, 1984; Morrison et al., 1984; Magistretti and Morrison, 1985). It seems that the distribution of CRF-positive neurons is somewhat more widespread in the rat than the cat visual cortex, since a number of CRF-positive neurons have been reported outside layers I-II in the rat. While it has been generally accepted that NPY-positive cells occur mainly in the infragranular layers in different species (McDonald et al., 1982d; Chan-Palay et al., 1985; Wahle et al., 1986), there is less agreement on the laminar distribution of SRIF-positive cells. In the rabbit (Ramon y Cajal et al., 1985) and the rat (Finley et al., 1981; McDonald et al., 1982a; Laemle and Feldman, 1985; Lin et al., 1986; Meinecke and Peters, 1986), a majority of authors report more SRIF-positive neurons in layers II and III than in layers V and VI of the rabbit cortex. These results suggest that the distribution of SRIF-positive cells

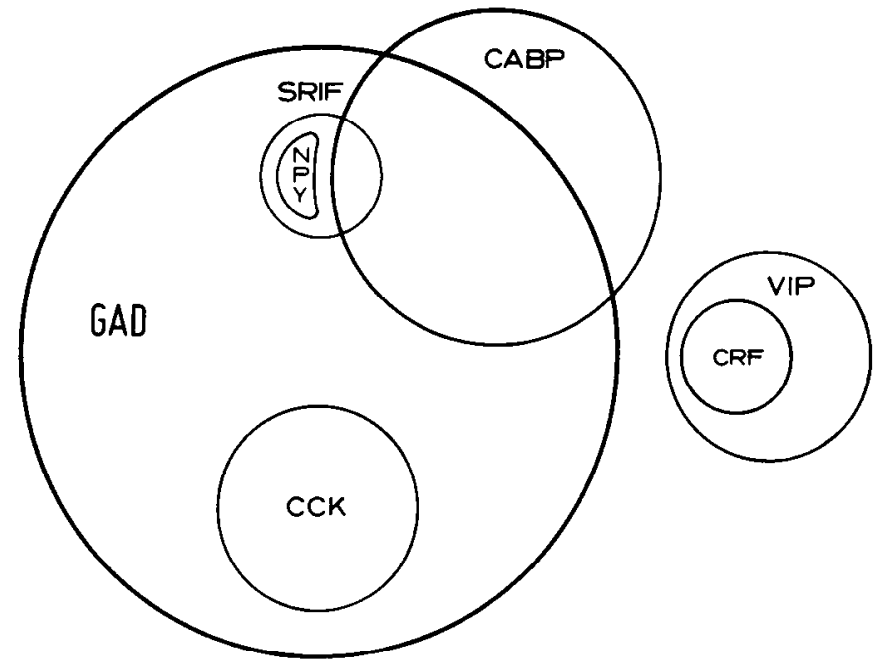

Figure 8. Diagrams showing the different populations of immunoreactive neurons in the cat primary visual cortex. The GAD-containing neuronal population is subdivided according to the colocalization of the different peptides (CCK, SRIF, and NPY) and the partial coexistence with CaBP. Neurons containing SRIF and GAD are either positive for NPY or for CaBP. All VIP-immunoreactive neurons do not coexist with GAD, but some of them coexist with CRF.

in the rabbit and rat visual cortex is more widespread than in the cat visual cortex. In general, the morphology of peptidergic cells is very similar in the cat and rat visual cortex. CCK-positive cells, however, are mainly bitufted or multipolar in the cat cortex and chiefly bipolar or multipolar in the rat cortex. Another exception is the morphology of VIP-positive cells, which are virtually all bipolar in the rat cortex (McDonald et al., 1982b; Connor and Peters, 1984; Eckenstein and Baughman, 1984), but are either bipolar or bitufted in the cat.

Distribution of a vitamin $D$-dependent calcium-binding protein Brain CaBP has been localized immunocytochemically in different species (Pochet et al., 1985; Stichel and Singer, 1985b). This protein is vitamin $\mathrm{D}$-dependent and plays an important role in Ca resorption in kidney and intestine. In the brain, this protein has been shown not to depend on vitamin D (Schneeberger et al., 1985; Pasteels et al., 1986), and its functional role remains unclear. Pochet et al. (1985) have suggested that the protein may function as a cytoplasmatic calcium buffer. Our results on the distribution of CaBP-positive neurons are in agreement with those of Stichel and Singer (1985b), who demonstrated that the CaBP-positive neurons are concentrated in the upper layers and that the number of positive cells decreases gradually from layers I to VI. The vitamin D-dependent calcium-binding protein used in the present experiments is only one of several calcium-binding proteins present in the brain. Parvalbumin, another calcium-binding protein, has also been found to coexist with GABA in rat cortical cells (Celio, 1986). Although interspecies comparisons are difficult to make, it is worth pointing out that both the proportion of double-labeled cells and their laminar distribution are different for parvalbumin and CaBP. While $70 \%$ of the GABA-positive cells also contained parvalbumin in the rat cortex, only $20 \%$ of the GAD-positive cells contained CaBP in our experiments. Neurons containing parvalbumin and GABA were preferentially associated with lay- 
ers II-VI of the rat cortex; cells double-labeled for GAD and $\mathrm{CaBP}$ occurred mainly in layers II and III of the cat cortex.

\section{Double-labeled cells}

As reported earlier (Hendry et al., 1984b; Schmechel et al., 1984; Somogyi et al., 1984a; Lin et al., 1986), the GAD-positive population can be subdivided into several subpopulations according to colocalization of the neuropeptides SRIF, NPY, and CCK. In addition, we found immunocytochemical evidence that the remaining GAD-positive neurons may be subdivided according to CaBP colocalization. Our data show that the GAD-positive cells can be subdivided into at least 4 broad groups: (1) cells that are only GAD-positive, (2) cells that are labeled by antibodies against GAD and $\mathrm{CaBP},(3) \mathrm{GAD}$-positive cells that also contain CCK, and (4) GAD-positive cells that also contain SRIF. A small subset of class 2 also contains SRIF, and most cells of class 4 also contain NPY. The 4 classes of GAD-positive cells differ in laminar position: class 1 predominates in layers IV and V, as was reported by Hendry et al. (1984b); classes 2 and 3 predominate in the upper layers (II and III), and class 4 predominates in the deepest layer (VI). We suggest that these different biochemical types of GAD-positive cells may subserve different functional roles in the visual cortex, in which many functional properties depend on GABAergic inhibition. Our results are at variance with the findings of Merchenthaler et al. (1982) and Merchenthaler (1984), who reported that, in the rat cortex, VIP- and CRF-positive cells are 2 distinct populations. Our results show that, at least in cat visual cortex, VIP and CRF are colocalized. Furthermore, these cells do not contain GAD in concentrations detectable with our techniques.

\section{Functional implications}

Phillis and I imacher (1974) and Phillis and Kirkpatrick (1980) reported that the iontophoretic application of different neuropeptides can exert an excitatory or inhibitory action on cortical neurons. In addition, Sheehan and de Belleroche (1983) showed that CCK application facilitated the release of GABA by rat cortical neurons. These reports, together with the general observation that neuropeptides coexist with GAD, suggest that neuropeptides could play a role in the processing of visual information in the cat visual cortex. For example, CCK or SRIF, by their corelease with GABA, could potentiate the GABAergic inhibition responsible for orientation, direction selectivity, or end-stopping. Peptidergic cells and fibers are very scarce in lamina IV, the chief target of geniculate afferents, while cells in this lamina are orientation-selective and can also be end-stopped or direction-selectivc. This suggests that peptidergic innervation plays little or no role in the elaboration of the parameter specificities of cortical cells, although there is evidence that orientation selectivity arises independently in the superficial layers (Malpeli, 1983), and peptide corelease with GABA could contribute to this specificity in these layers. The rather negative results of Salt and Sillito (1984) and Sillito (1986) with the iontophoretic application of SRIF or CCK also argue against an important role of peptides in visual processing. While the laminar distribution of peptidergic cells bears little relation to the termination of geniculate afferents, it follows relatively closely the laminar distribution of cortical feedback projections (Rockland and Pandya, 1981; Bullier et al., 1984), and also matches the laminar distribution of output cells (Gilbert and Kelly, 1975). This suggests that peptides could have a modulatory action on the level of activity of cortical output, or on the degree to which feedback projections influence a cortical area. This suggestion is supported by the fact that receptors for peptides are located mainly in the supragranular or infragranular layers (Leroux and Pelletier, 1984; Tran et al., 1984; Shaw and Cynader, 1985; Martel et al., 1986; Reubi et al., 1986; Shaffer and Moody, 1986; Shaw and Cynader, 1986). In contrast, the highest density of GABA (muscimol) binding sites is found in layer IV (Needler et al., 1984) of the cat's area 17. The observation that the laminar distribution of peptidergic cells matches that of output cells could also suggest that neuropeptide release might signal local neuronal activity in a cortical area, and that this signal may be used for the control of local blood flow and local metabolism. Sillito (1986) argues that this effect of some peptide-containing neurons (on cortical blood flow and metabolism) is clearly commensurate with what he calls "slow chemical signals." In principle, these signals would also play a role in long-term neuronal changes underlying plasticity, but there is little evidence for a laminar difference in cortical plasticity. VIP-containing bipolar neurons constitute the main group of peptide-positive cells, which do not contain GAD. In addition, a small subset of CCK-positive bipolar cells can also belong to this group (Hendry et al., 1983a). These 2 groups of bipolars share the common feature of making synaptic contact with blood vessels, as well as with other cortical cells. Magistretti et al. (1984) and Magistretti and Morrison (1985) have suggested that, in the rat, VIP-positive cortical neurons play a role in the coupling of energy metabolism, blood flow, and neuronal activity. As discussed by the latter authors, the concomitant release of a discrete cortical volume of noradrenaline and VIP generates a metabolic "hot spot" where cAMP levels increase drastically in comparison with surrounding regions. The VIP bipolar neurons involved in this coupling are found in a $1 / 1$ ratio in the cortical hypercolumns. It is not clear whether VIP-positive cells play a similar role in the cat, since there are some differences between VIPpositive cells in rat and cat visual cortex. Eckenstein and Baughman (1984) demonstrated that, in the rat, at least $80 \%$ of the VIP-positive cells are also cholinergic. Up to now, no cholinergic cells have ever been observed in the cat visual cortex (Kimura et al., 1981; Stichel and Singer, 1985a; de Lima and Singer, 1986). Furthermore, as mentioned above, the morphology of cortical VIP-positive cells is not exactly the same in the rat as in the cat. Therefore, elucidation of the function of peptidergic cells in the metabolic events of the visual cortex, and of the functional role of peptides in general, requires further experimentation.

\section{References}

Brandon, C. (1986) Purification of L-glutamate decarboxylase from rabbit brain and preparation of a monospecific antiserum. J. Neurosci. Res. 15: 367-389.

Bullier, J., H. Kennedy, and W. Salinger (1984) Branching and laminar origin of projections between visual cortical areas in the cat. J. Comp. Neurol. 228: 329-341.

Celio, M. R. (1986) Parvalbumin in most $\gamma$-aminobutyric acid containing neurons of the rat cerebral cortex. Science 231: 995-997.

Chan-Palay, V., Y. S. Allen, W. Lang, U. Hacsler, and J. M. Polak (1985) I. Cytology and distribution in normal human cerebral cortex of neurons immunoreactive with antisera against neuropeptide-Y. J. Comp. Neurol. 238: 382-389.

Connor, J. R., and A. Peters (1984) Vasoactive intestinal polypeptideimmunoreactive neurons in rat visual cortex. Neuroscience 12: $1027-$ 1044.

de Lima, A. D., and W. Singer (1986) Cholinergic innervation of the 
cat striate cortex: A choline acetyltransferase immunocytochemical analysis. J. Comp. Neurol. 250: 324-338.

Dierickx, K., and F. Vandesande (1979) Immunocytochemical localization of somatostatin containing neurons in the rat hypothalamus. Cell Tissue Res. 201: 349-359.

Eckenstein, F., and R. W. Baughman (1984) Two types of cholinergic innervation in cortex, one co-localized with vasoactive intestinal polypeptide. Nature 309: 153-155.

Finley, J. C. W., J. L. Maderdrut, L. J. Roger, and P. Petrusz (1981) The immunocytochemical localization of somatostatin-containing neurons in the rat central nervous system. Neuroscience 6: 21732192.

Fitzpatrick, D., J. S. Lund, and D. Schmechel (1983) Glutamic acid decarboxylase immunoreactive neurons and terminals in the visual cortex of monkey and cat. Soc. Neurosci. Abstr. 9: 616.

Freund, T. F., K. A. C. Martin, A. D. Smith, and P. Somogyi (1983) Glutamate decarboxylase-immunoreactive terminals of Golgi-impregnated axoaxonic cells and of presumed basket cells in synaptic contact with pyramidal neurons of the cat's visual cortex. J. Comp. Neurol. 221: 263-278

Gabbott, P. L. A., and P. Somogyi (1986) Quantitative distribution of GABA-immunoreactive neurons in the visual cortex (area 17) of the cat. Exp. Brain Res. 61: 323-331.

Gilbert, C. D., and J. P. Kelly (1975) The projections of cells in different layers of the cat's visual cortex. J. Comp. Neurol. 163: 81106.

Hendrickson, A. E., S. P. Hunt, and J.-Y. Wu (1981) Immunocytochemical localization of glutamic acid decarboxylase in monkey striate cortex. Nature 292: 605-607.

Hendry, S. H. C., E. G. Jones, and M. C. Beinfeld (1983a) Cholecystokinin immunoreactive neurons in rat and monkey cerebral cortex make symmetric synapses and have intimate associations with blood vessels. Proc. Natl. Acad. Sci. USA 80: 2400-2404.

Hendry, S. H. C., C. R. Houser, E. G. Jones, and J. E. Vaughn (1983b) Synaptic organization of immunocytochemically identified GABA neurons in the monkey sensory-motor cortex. J. Neurocytol. 12:639660 .

Hendry, S. H. C., E. G. Jones, and P. C. Emson (1984a) Morphology, distribution, and synaptic relations of somatostatin- and neuropeptide $\mathrm{Y}$-immunoreactive neurons in rat and monkey neocortex. J. Neurosci. 4: 2497-2517.

Hendry, S. H. C., E. G. Jones, J. DeFelipe, D. Schmechel, C. Brandon, and P. C. Emson (1984b) Neuropeptide-containing neurons of the cerebral cortex are also GABA-ergic. Proc. Natl. Acad. Sci. USA 81: 6526-6530.

Houser, C. R., S. H. C. Hendry, E. G. Jones, and J. E. Vaughn (1983) Morphological diversity of immunocytochemically identified GABA neurons in the monkey sensory-motor cortex. J. Neurocytol. 12:617638.

Jones, E. G., and S. H. C. Hendry (1986) Co-localization of GABA and neuropeptides in neocortical neurons. Trends Neurosci. 9: 7176.

Kimura, H., P. L. McGeer, J. H. Peng, and E. G. McGeer (1981) The central cholinergic system studied by choline acetyltransferase immunohistochemistry in the cat. J. Comp. Neurol. 200: 151-201.

Laemle, L. K., and S. C. Feldman (1985) Somatostatin (SRIF)-like immunoreactivity in subcortical and cortical visual centers of the rat. J. Comp. Neurol. 233: 452-462.

Leroux, P., and G. Pelletier (1984) Radioautographic localization of somatostatin- 14 and somatostatin- 28 binding sites in the rat brain. Peptides 5: 503-506.

Lin, C., S. M. Lu, and D. E. Schmechel (1986) Glutamic acid decarboxylase and somatostatin immunoreactivities in rat visual cortex. J. Comp. Neurol. 244: 369-383.

Lotstra, F., and J. J. Vanderhaeghen (1984) Possible misinterpretations of radioimmunoassay results of endocrine tissues containing peptides in the micromolar range. Med. Biol. 62: 59-63.

Magistretti, P. J., and J. H. Morrison (1985) VIP neurons in the neocortex. Trends Neurosci. 8: 7-8.

Magistretti, P. J., J. H. Morrison, W. J. Shoemaker, and F. E. Bloom (1984) Morphological and functional correlates of VIP neurons in cerebral cortex. Peptides 5: 213-218.

Malpeli, J. G. (1983) Activity of cells in area 17 of the cat in absence of input from layer A of lateral geniculate nucleus. J. Neurophysiol. 49: 595-610.
Martel, J. C., S. St.-Pierre, and R. Quirion (1986) Neuropeptide Y receptors in rat brain: Autoradiographic localization. Peptides 7:5560.

McDonald, J. K., J. G. Parnavelas, A. N. Karamanlidis, N. Brecha, and J. I. Koenig (1982a) The morphology and distribution of peptidecontaining neurons in the adult and developing visual cortex of the rat. I. Somatostatin. J. Neurocytol. 11: 809-824.

McDonald, J. K., J. G. Parnavelas, A. N. Karamanlidis, and N. Brecha (1982b) The morphology and distribution of peptide-containing neurons in the adult and developing visual cortex of the rat. II. Vasoactive intestinal polypeptide. J. Neurocytol. 11: 825-837.

McDonald, J. K., J. G. Parnavelas, A. N. Karamanlidis, G. Rosenquist, and N. Brecha (1982c) The morphology and distribution of peptidecontaining neurons in the adult and developing visual cortex of the rat. III. Cholecystokinin. J. Neurocytol. 11:881-895.

McDonald, J. K., J. G. Parnavelas, A. N. Karamanlidis, and N. Brecha (1982d) The morphology and distribution of peptide-containing neurons in the adult and developing visual cortex of the rat. IV. Avian pancreatic polypeptide. J. Neurocytol. 11: 985-995.

Meinecke, D. L., and A. Peters (1986) Somatostatin immunoreactive neurons in rat visual cortex: A light and electron microscopic study. J. Neurocytol. 15: 121-136.

Merchenthaler, I. (1984) Corticotropin releasing factor (CRF)-like immunoreactivity in the rat central nervous system. Extrahypothalamic distribution. Peptides 5: 53-69.

Merchenthaler, I., S. Vigh, P. Petrusz, and $\Lambda$. V. Schally (1982) Immunocytochemical localization of corticotropin-releasing factor (CRF) in the rat brain. Am. J. Anat. 165: 385-396.

Morrison, J. H., P. J. Magistretti, R. Benoit, and F. E. Bloom (1984) The distribution and morphological characteristics of the intracortical VIP-positive cell: An immunohistochemical analysis. Brain Res. 292: 269-282.

Needler, M. C., C. Shaw, and M. Cynader (1984) Characteristics and distribution of muscimol binding sites in cat visual cortex. Brain Res. 308: 347-353.

Pasteels, J. L., R. Pochet, L. Surardt, C. Hubeau, M. Chirnoaga, M, Parmentier, and D. E. M. I awson (1986) Ultrastructural localization of brain "Vitamin D-dependent" calcium binding proteins. Brain Res. 384: 294-303.

Peters, A., M. Miller, and L. M. Kimerer (1983) Cholecystokinin-like immunoreactive neurons in rat cerebral cortex. Neuroscience $8: 431-$ 448 .

Phillis, J. W., and J. H. Kirkpatrick (1980) The actions of motilin, luteinizing hormone releasing hormone, cholecystokinin, somatostatin, vasoactive intestinal polypeptide and other peptides on rat cerebral cortical neurons. Can. J. Physiol. Pharmacol. 58: 612-623.

Phillis, J. W., and J. J. Limacher (1974) Excitation of cerebral cortical neurons by various polypeptides. Exp. Neurol. 43: 414-423.

Pochet, R., M. Parmentier, D. E. M. Lawson, and J. L. Pasteels (1985) Rat brain synthetizes two "vitamin D dependent" calcium binding proteins. Brain Res. 345: 251-256.

Ramon y Cajal, S., P. Contamina, P. Parra, L. Martinez-Millan, J. A. De Carlos, and C. Ramo (1985) The distribution of somatostatin immunoreactive neurons in the visual cortex of adult rabbits and during postnatal development. Brain Res. 359: 379-382.

Reubi, J. C., R. Cortès, R. Maurer, and A. Probst (1986) Distribution of somatostatin receptors in the human brain: An autoradiographic study. Neuroscience 18: 329-346.

Ribak, C. E. (1978) Aspinous and sparsely spinous stellate neurons in the visual cortex of rats contain glutamic acid decarboxylase. J. Neurocytol. $7: 461-478$.

Rockland, K. S., and D. N. Pandya (1981) Cortical connections of the occipital lobe in the rhesus monkey: Interconnections between areas $17,18,19$ and the superior temporal sulcus. Brain Res. 212: 249270 .

Salt, T. E., and A. M. Sillito (1984) The action of somatostatin (sst) on the response properties of cells in the cat's visual cortex. From the proceedings of the Physiological Society. J. Neurophysiol. $350: 28 \mathrm{pp}$.

Schmechel, D. E., B. G. Vickrey, D. Fitzpatrick, and R. P. Elde (1984) GABAergic neurons of mammalian cerebral cortex: Widespread subclass defined by somatostatin content. Neurosci. Lett. 47: 227-232.

Schneeberger, P. R., A. W. Norman, and C. W. Heizman (1985) Parvalbumin and vit D-dependent calcium-binding protein (Mr 28000): Comparison of their localization in the cerebellum of normal and rachitic rats. Neurosci. Lett. 59: 97-103. 
Shaffer, M. M., and T. W. Moody (1986) Autoradiographic visualization of CNS receptors for vasoactive intestinal polypeptide. Peptides 7: 283-288.

Shaw, C., and M. Cynader (1985) Altcrations in the laminar distribution of pentagastrin binding sites in cat visual cortex during postnatal development. Dev. Brain Res. 20: 132-136.

Shaw, C., and M. Cynader (1986) Laminar distribution of receptors in monkey (Macaca fascicularis) geniculostriate system. J. Comp. Neurol. 248: 301-312.

Sheehan, M. J., and J. de Belleroche (1983) Facilitation of GABA release by cholecystokinin and caerulein in rat cerebral cortex. Neuropeptides $3:$ : $429-434$.

Sillito, A. M. (1974) Effects of the iontophoretic application of bicuculline on the receptive field properties of the simple cells in the visual cortex of the cat. J. Physiol. (Lond.) 242: 1279-1289.

Sillito, A. M. (1975a) The effectiveness of bicuculline as an antagonist of GABA and visually evoked inhibition in the cat's striate cortex. J. Physiol. (Lond.) 250: 287-304.

Sillito, A. M. (1975b) The contribution of inhibitory mechanisms to the receptive field properties of neurones in the striate cortex of the cat. J. Physiol, (Lond.) 250: 305-329.

Sillito, A. M. (1986) Fast and slow chemical signalling in the visual cortex: An evaluation of GABA- and neuropeptide-mediated influences. In Fast and Slow Chemical Signalling in the Nervous System, Iversen and Goodman, eds., pp. 56-74, Oxford U. P., Oxford, UK.

Sillito, A. M., J. A. Kemp, J. A. Milson, and N. Berardi (1980) A reevaluation of the mechanism underlying simple cell orientation selectivity. Brain Res. 194: 517-520.

Skowsky, W. R., and D. A. Fisher (1972) The use of thyroglobulin to induce antigenicity to small molecules. J. Lab. Clin. Med. 80:134 144.

Somogyi, P., and A. J. Hodgson (1985) Antiserum to $\gamma$-aminobutyric acid: III. Demonstration of GABA in Golgi-impregnated neurons and in conventional electron microscopic sections of cat striate cortex. J. Histochem. Cytochem. 33: 249-257.

Somogyi, P., T. F. Freund, J. Y. Wu, and A. D. Smith (1983) The section-Golgi impregnation procedure. 2 . Immunocytochemical demonstration of glutamate decarboxylase in Golgi-impregnated neurons and in their afferent synaptic boutons in the visual cortex of the cat. Neuroscience 9: 475-490.

Somogyi, P., A. J. Hodgson, A. D. Smith, M. G. Nunzi, A. Gorio, and J. Y. Wu (1984a) Different populations of GABAergic neurons in the visual cortex and hippocampus of cat contain somatostatin- or cholecystokinin-immunoreactive material. J. Neurosci. 4: 2590-2603.

Somogyi, P., T. F. Freund, and Z. F. Kisvarday (1984b) Different types of $3 \mathrm{H}-\mathrm{GABA}$ accumulating neurons in the visual cortex of the rat. Characterization by combined autoradiography and Golgi impregnation. Exp. Brain Res. 54: 45-56.

Somogyi, P., T. F. Freund, A. J. Hodgson, J. Somogyi, D. Beroukas, and I. W. Chubb (1985) Identified axo-axonic cells are immunoreactive for GABA in the hippocampus and visual cortex of the cat. Brain Res. 332: 143-149.

Sternberger, L. A., P. H. Hardy, J. J. Cuculis, and H. G. Meyer (1970) The unlabelled antibody-enzyme method of immunohistochemistry. Preparation and properties of soluble antigen-antibody complex (horseradish peroxidase anti-horseradish peroxidase) and its use in identification of spirochetes. J. Histochem. Cytochem. 18: 315-317.

Stichel, C. C., and W. Singer (1985a) Organization and morphological characteristics of choline acetyltransferase-containing fibers in the visual thalamus and striate cortex of the cat. Neurosci. Lett. 53: 155160.

Stichel, C. C., and W. Singer (1985b) Developmental changes in the distribution of calcium binding proteins in the cal visual system. Neurosci. Lett. (Suppl.) 22: 356.

Swanson, L. W., P. E. Sawchenko, J. Rivier, and W. W. Vale (1983) Organization of ovine corticotropin-releasing factor immunoreactive cells and fibers in the rat brain: An immunohistochemical study. Neuroendocrinology $36: 165-186$.

Tran, V. T., G. R. Uhl, D. C. Perry, D. C. Manning, W. W. Vale, M. H. Perrin, J. E. Rivier, J. B. Martin, and S. H. Snyder (1984) Autoradiographic localization of somatostatin receptors in rat brain. Eur. J. Pharmacol. 101: 307-309.

Vandesande, F. (1983) Immunohistochemical double staining techniques. In Immunohistochemistry, A. C. Cuello, ed., pp. 257-272, Wiley, New York.

Vandesande, F., K. Dierickx, and J. De Mey (1977) The origin of the vasopressinergic and oxytocinergic fibres of the median eminence of the rat hypophysis. Cell Tissue Res. 180:443-452.

Vidyasagar, T. R., and W. Heide (1986) The role of GABAergic inhibition in the response properties of neurons in cat visual area 18 . Neuroscience 17: 49-55.

Wahle, P., G. Meyer, and K. Albus (1986) Localization of NPYimmunoreactivity in the cat's visual cortex. Exp. Brain Res. 61:364 374. 